\title{
Incomes, Exchange Rates and the US Trade Deficit, Once Again*
}

\author{
Menzie D. Chinn \\ University of Wisconsin, Madison, and NBER.
}

\begin{abstract}
The chronic and expanding US trade deficit has refocused attention upon the responsiveness of trade flows to exchange rate and income changes. I estimate import and export equations over a period spanning the 1990s New Economy boom and the subsequent recession and dollar depreciation. The results indicate (1) a low responsiveness of imports to exchange rate changes, and (2) a diminution (but not disappearance) of the income elasticity asymmetry first noted by Houthakker and Magee. The combination of low price elasticity of imports with the present size of the trade deficit means that any reduction of the trade deficit will necessarily be accompanied by large exchange rate and income trend adjustments.
\end{abstract}

\section{Introduction}

The ever-expanding US trade deficit has prompted recurring predictions of a current account adjustment and dollar depreciation. Although these predictions have yet to be validated - indeed as of the first quarter of 2004, the

\footnotetext{
*I thank the editor Benn Steil, three anonymous referees, Yin-Wong Cheung, Neil Ericsson, Joe Gagnon, Bill Helkie, Robert Z. Lawrence, Catherine Mann and Jaime Marquez, and participants at the 2004 IEFS panel on 'Income and Trade Elasticities 35 Years Later' for helpful comments on this paper, which draws on NBER Working Paper No. 9521. The views reported herein are solely the author's, and do not necessarily represent those of the institutions the author is currently or previously affiliated with.
} 
trade deficit/GDP ratio exceeded the $4.7 \%$ level despite a $25 \%$ decline in the trade-weighted value of the dollar since its recent peak in $2002^{1}$ - most observers would agree that at some time in the future the trade and current account balances must move towards surplus. ${ }^{2}$

How the external adjustment US economy takes place is of interest to economists in both the policy-making and academic communities. ${ }^{3}$ For the latter, the issue is whether the observed correlations summarized by the estimated elasticities prove durable, or are a function of other, deeper factors. Of specific interest is the question as to whether the well-known income elasticity asymmetry first noted by Houthakker and Magee (1969) persists. For the former group, the question is how much of a real exchange rate adjustment, combined with changing growth rates at home and abroad, is necessary to effect the adjustment of the US economy to the lower capital inflows that are anticipated. This question has even greater importance for policy makers in the rest of the world, since the United States is a relatively closed economy, and the magnitude of the implied dollar shifts will have large effects upon the relatively more open economies in East Asia and Latin America.

Hence, in both arenas, there is some urgency to the mission of estimating the macroeconomic determinants of aggregate trade flows. Indeed, in an interesting confluence of policy and academic concerns, some have pinned hopes for stabilizing the trade deficit on a convergence of the income elasticities of the US and its trading partner economies, combined with accelerated growth in the rest of the world.

This study first surveys the recent literature on the determinants of trade flows. It then adds to the current literature by updating the estimates of price and income elasticities for US imports and exports. Finally, the implications of these point estimates are recounted.

To anticipate the empirical results, I find that there is a statistically significant relationship between total exports of goods and services, US income and the real exchange rate. However, for total US imports, there appears to be little evidence of such a link. Only by excluding computer and computer parts from total imports can I identify a long-run import relationship involving the real exchange rate. Furthermore, in these sets of estimates, the income elasticity asymmetry of Houthakker and Magee (1969)

\footnotetext{
${ }^{1}$ Trade balance figures from 26 June release. The trade-weighted value of the dollar is the consumer price index (CPI)-adjusted major currencies index of the Federal Reserve Board.

${ }^{2}$ For a contrasting view, see Dooley et al. (2003).

${ }^{3}$ See Baily (2002) for an extensive discussion of sector-specific as well as macroeconomic issues related to a large dollar depreciation.
} 


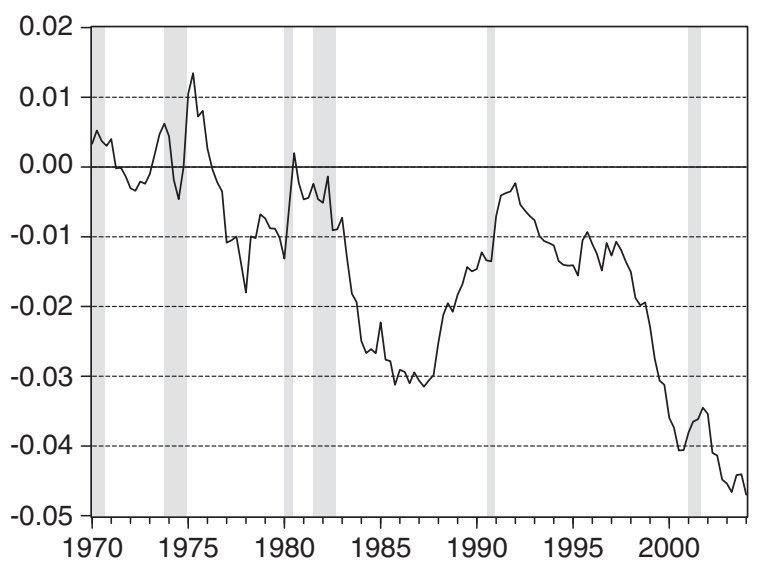

Source: BEA (National income and product accounts, 26 June, 2004), and NBER.

Figure 1: Nominal US trade balance to GDP ratio (seasonally adjusted at annual rate, SAAR) and recessions (shaded areas)

is diminished, ${ }^{4}$ so that similar growth rates at home and abroad no longer necessitate as rapid a secular dollar depreciation in order to maintain balanced trade.

\section{The Context}

In the first quarter of 2004, the nominal trade deficit reached $-\$ 538.2$ billion at a seasonally adjusted annual rate, or $4.7 \%$ of GDP (see Figure 1). In absolute terms, this was a record, and even expressed in proportion to GDP this was a substantial figure. At the same time, the real value of the dollar, as measured by the Federal Reserve, was approximately $36.5 \%$ below its peak in 1985 . However, only two years earlier it had been only $11 \%$ below that value (see Figure 2). To the extent that the strong value of the dollar had priced some American goods out of international competition, it might be argued that a depreciation of the dollar will bring about a commensurate adjustment of the trade deficit.

There are two reasons to question this view. First, it is not clear that this measure of the dollar's value is the most appropriate. Second, it is similarly unclear that the drop of the dollar that has occurred thus far would be

\footnotetext{
${ }^{4}$ This study is not the first one to provide an explanation for the income elasticity asymmetry. Helkie and Hooper (1988) argue that inclusion of relative supply, via a relative capital stock measure, makes the gap in elasticities disappear. Arora et al. (2001) find that estimated income elasticities for exports and imports appear to be converging.
} 


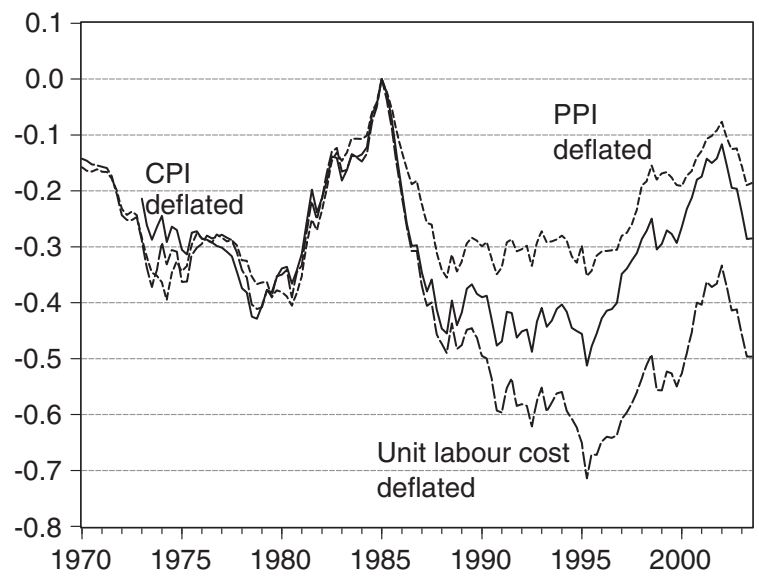

Sources: Federal Reserve Board, J. P. Morgan and IMF.

Figure 2: Indices of the US trade-weighted value of the dollar (in logs, normalized to $1985 \mathrm{q} 1=0)$

sufficient to effect the trade balance adjustment that many observers view as necessary.

Turning to the first point, note that alternative measures of the value of the dollar yield different stories about the dollar's strength. For instance, if costs of production - rather than prices - are the metric, then by the IMF's reckoning, the dollar is some $50 \%$ below its previous peak. Consequently, if this is the more relevant measure, then the deterioration in the trade balance is not because of an overly strong currency, since the dollar has been in fact relatively weak over the last few years. On the other hand, if producer (rather than consumer) prices are more relevant for the determination of trade flows, then according to the J. P. Morgan index, the dollar has indeed been near its 1985 peak, and dollar overvaluation may be a chief cause of the trade deficit.

The insightful observer will note that, in any event, a dollar depreciation is required to reduce the deficit. But any depreciation would be insufficient to permanently remedy the situation because of the Houthakker-Magee finding that the income sensitivity of imports exceeds that of exports by about 0.5 . Hence, one perspective is that in the absence of secular dollar decline irrespective of measurement - the trade deficit would continue to expand even if US income growth is the same as the rest of the world's.

It is against this backdrop that one needs to evaluate these questions. What is the proper measure of the dollar's value? How much do trade flows respond to that measure? And how pronounced is the Houthakker-Magee asymmetry in the most recent period? The remainder of the paper examines these questions. 


\section{A Review of the Literature}

In order to examine the questions outlined above, an analytical framework is required. In particular, it is necessary to know what theory implies about the roles of income and relative prices.

The empirical specification commonly used to analyse the macroeconomic determinants of the trade balance is motivated by the traditional, partial equilibrium view of trade flows. In this framework, the demand for traded goods arises because not all the demand for goods can be satisfied by domestic production. When different countries produce goods that are viewed as different, then trade flows will be a function of price and activity variables. Goldstein and Khan (1985) provide a clear exposition of this 'imperfect substitutes' model.

Imposing the equilibrium conditions that supply equals demand, one can write out import and export equations (assuming log-linear functional forms):

$$
\begin{aligned}
& e x_{t}=\delta_{0}+\delta_{1} q_{t}+\delta_{2} y_{t}^{R o W}+u_{1 t} \\
& i m_{t}=\beta_{0}+\beta_{1} q_{t}+\beta_{2} y_{t}^{U S}+u_{2 t}
\end{aligned}
$$

where im, ex, $q$ and $y$ are (log) real imports, exports, real exchange rate and income, and $\delta_{1}>0, \delta_{2}>0, \beta_{1}<0$ and $\beta_{2}>0 .^{5}$

One can interpret equations (1) and (2) as semi-reduced-form equations. ${ }^{6}$ For instance, the second expression combines the relationship between the relative import price and imports and the relationship between the exchange rate and relative prices into one equation. To the extent that one takes the real exchange rate as 'more exogenous' than the relative price of imports, this approach makes more sense when the economic question at hand is 'what is the response of imports to a $1 \%$ change in the real exchange rate?'

I have sidestepped the more problematic issue of whether one can conduct policy experiments in this framework, as all these variables are in theory jointly determined. However, as Obstfeld and Rogoff (2000) remark, the

\footnotetext{
${ }^{5}$ The entire derivation is provided in Chinn (2003), and follows Rose (1991). Additional assumptions are required to obtain these specifications, including perfect supply elasticities. Typically, empirical studies in the cointegration framework have not relaxed this particular assumption.

${ }^{6}$ The interpretation of these parameters is structural. An alternative view is associated with Krugman (1989); there, the income elasticities are functions of income growth rates at home versus those abroad. Gagnon (2003) and Bayoumi (2003) provide additional information on the Krugman hypothesis.
} 
exchange rate often seems to have a life of its own, such that experiments of this nature may not be so unreasonable to consider. ${ }^{7}$

Rose and Yellen (1989) estimated regressions of the type outlined above, but focused on the trade balance. They examined monthly data over the 1960-85 period, and failed to detect evidence of any long-run relationship in levels, ${ }^{8}$ so they estimated these relationships in growth rates. In general, regardless of the estimation approach, they failed to find a significant impact of relative prices on the trade balance. For our purposes, the important point is that this finding held up to disaggregation to individual import and export flows.

Meade (1992) provided a useful update to the Rose and Yellen results. Using the additional data including the post-1987 adjustment in the trade deficit, she found that there was evidence of a long-run relationship between real non-agricultural exports with the real exchange rate and foreign income. Meade's results differ from Rose and Yellen's, largely because of the difference in sample period, which spanned the reduction in the trade deficit in the late 1980s. However, in her study, imports failed to exhibit evidence of a long-run relationship between the levels of the variables.

Recent work has relied on more powerful econometric techniques, such as the multivariate maximum likelihood estimation procedure of Johansen (1988). In conjunction with additional data, this procedure has provided more evidence of long-run relationships than obtained in previous studies. Johnston and Chinn (1996) find evidence of a long-run relationship between non-agricultural non-fuel trade flows, incomes and the real exchange rate over the 1973-93 period. Boyd et al. (2001) rely on the constrained Johansen estimation procedure. They too find evidence of long-run relationships over the 1975-95 period. The estimated income elasticity appears much in line with those obtained by many other studies (see Lawrence 1990; Mann 1999, Table 8.2).

Finally, an exhaustive study conducted by Hooper et al. (1998) also found evidence of a long-run relationship for both US exports and imports over the 1960-94 period, using relative prices (either import or export prices relative to broad deflators) or a real effective exchange rate. Interestingly, they obtain an incorrect sign for the price sensitivity for imports when using a real

\footnotetext{
${ }^{7}$ This 'exchange rate disconnect' - the seeming lack of connection between the exchange rate and other macro variables - is discussed in Devereux and Engel (2002), among others.

${ }^{8}$ In this paper, the phrase 'long-run relationship in levels' is equivalent to the term 'cointegration', coined by Engle and Granger. See Chinn (1991) for a general discussion.
} 
effective exchange rate index. That is, a weaker dollar is associated with greater imports, according to their results. ${ }^{9}$

In at least one of these studies, the income asymmetry first noted by Houthakker and Magee is reconfirmed. Hooper et al.'s estimations of income elasticities for total imports exceed those of exports by about 0.4-0.5. Unfortunately, since Boyd et al. restrict the income coefficients to be of equal and opposite value, this study does not shed any light on the issue.

\section{Updating the Conventional Wisdom}

I now turn to analysing the behaviour of US trade flows in a period that spans the New Economy boom and subsequent downturn in the US economy. The econometric approach is detailed in Appendix B, and is conducted on data obtained from a variety of sources. For measures of trade flows, national income and product accounts, data on real imports and exports of goods and services (1996 chain-weighted dollars) are used. These series are depicted in Figure 3. Domestic economic activity is measured by US GDP in 1996 chain-weighted dollars, while foreign economic activity is measured by rest-of-world GDP (expressed in 1996 dollars). This measure rest-of-world GDP is weighted by US exports to major trading partners.

Three different dollar indices are utilized. (All three of these series in logs are depicted in Figure 2, rescaled to equal 0 in 1985q1, and expressed so that higher values indicate a lower exchange rate, or stronger dollar.) The first is the Federal Reserve's major currencies trade-weighted value of the dollar; the second is the J. P. Morgan broad trade-weighted index, deflated using the PPI. The third is the IMF's trade-weighted index deflated using unit labour costs (ULCs). ${ }^{10}$

The first two variables approximate measures of 'price competitiveness'. On theoretical grounds the PPI-deflated measure is preferable to the CPI-deflated measure because the latter incorporates the prices of many

\footnotetext{
${ }^{9}$ Note that Hooper et al. (1998) directed their attention primarily at empirical results pertaining to the response of trade flows to relative prices (e.g. the price of imports relative to the general price deflator), rather than to real exchange rates. Those elasticities were correctly signed.

${ }^{10}$ The various exchange rate indices also differ in terms of their construction. The Federal Reserve index only covers the major trading partners, while the J. P. Morgan series covers 23 countries. The IMF series comparing unit labour costs only covers industrialized countries for which detailed cost data are available. See Chinn (2004) for a detailed discussion of the characteristics of these indices.
} 


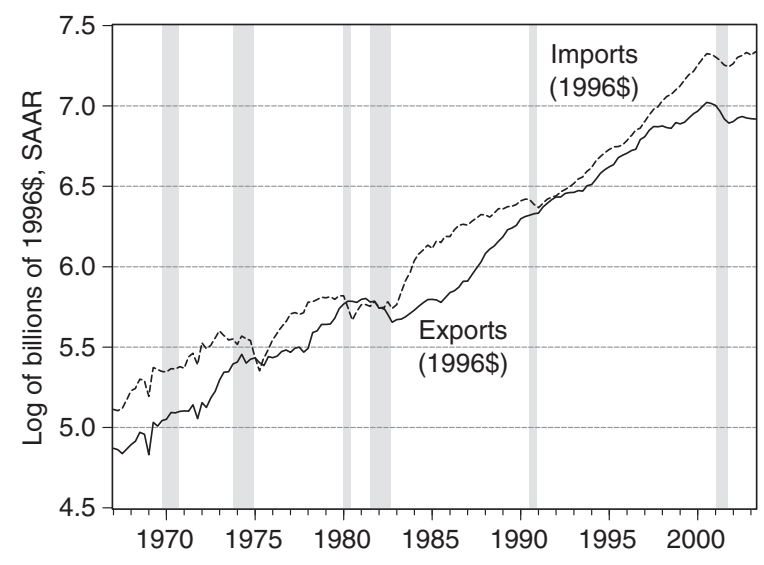

Source: BEA (National income and product accounts, 15 December 2003), and NBER.

Figure 3: Exports and imports of goods and services, in logged chained 1996 (SAAR) and recession dates

non-traded goods that are unlikely to be relevant to flows of traded goods. On the other hand, the fact that CPIs are widely available and are more comparable across developed economies may lend the CPI-deflated measure a practical advantage.

The third measure merits some additional discussion. The ULC-deflated measure is best thought of as an empirical proxy for 'cost competitiveness'. Assuming that prices are determined by wages and a fixed cost-markup, then the real exchange rate is the nominal rate adjusted by wages and productivity levels. As productivity levels rise, the real dollar cost of production falls. In contrast, rising US wages cause an appreciated real dollar. This definition of the real exchange rate also fits in with a Ricardian model of trade (Golub 1994). However, it is likely to be an imperfect measure of cost competitiveness, as it only incorporates labour, rather than total costs, and even these are imprecisely measured. In addition, the limited availability of ULC data means that this index encompasses only a smaller set of trading partners.

The empirical exercise is applied to data spanning a period of 1975q12003q2. This period includes two episodes of dollar appreciation and two episodes of dollar depreciation.

The estimation procedure (described in Appendix B) provides estimates of the long-run coefficients as well as the error correction coefficients, parameters describing how fast each of the variables adjusts back to the long-run equilibrium. The error correction coefficients relating changes in import and export flows and the deviations from long-run equilibrium should be negative, and statistically significant, indicating that imports (or 
Table 1: US Exports Equation, 1975q1-2003q2

\begin{tabular}{lcccc}
\hline Long-run coeff & Pred & CPI defl. [1] & PPI defl. [2] & ULC defl. [3] \\
\hline C.V.[asy.] & & 2,2 & 1,1 & 1,1 \\
C.V.[f.s.] & & 2,1 & 1,1 & 1,1 \\
$q$ & $(+)$ & $2.281^{*}(0.596)$ & $1.949^{*}(0.622)$ & $0.726^{* * *}(0.090)$ \\
$y$ & $(+)$ & $1.695(0.233)$ & $1.987(0.205)$ & $1.615^{*}(0.053)$ \\
lag & 2 & 2 & 2 \\
$N$ & 114 & 114 & 114 \\
Error correction coefficients & & & \\
Ex & $(-)$ & $-0.011^{* * *}(0.005)$ & $-0.009(0.006)$ & $-0.168^{* * *}(0.030)$ \\
$q$ & $(-)$ & $0.008(0.006)$ & $0.007(0.006)$ & $-0.052(0.048)$ \\
$y$ & $(+)$ & $-0.001^{* * *}(0.000)$ & $0.002^{* * *}(0.000)$ & $-0.003^{* *}(0.001)$ \\
\hline
\end{tabular}

Notes: 'Coeff' is the coefficient from equation (A2) (standard errors in parentheses). 'Pred' indicates predicted sign. 'C.V.' indicates the number of cointegrating vectors identified using the trace, maximal eigenvalue statistics, and the $1 \%$ significance level; [asy.] indicates asymptotic critical values, while [f.s.] indicates use of finite sample critical values (Cheung and Lai 1993). Coefficients are long-run parameter estimates from the Johansen procedure described in the text. Lag is the number of lags in the VAR specification of the system. $N$ is the effective number of observations included in the regression.

* Denotes significance at the $10 \%$ level.

**Denotes significance at the $5 \%$ level.

$* * *$ Denotes significance at the $1 \%$ level, using a likelihood ratio test for the relevant zero restriction.

exports) respond by closing the gap. ${ }^{11}$ If in addition incomes respond, the error correction coefficients relating income changes to disequilibria should be positive.

The regression results for exports of goods and services are reported in Table 1. Overall, the results are favourable towards a finding of a long-run relationship; in all cases evidence of cointegration is obtained, according to the trace and maximal eigenvalue statistics. The sensitivity of exports to the real exchange rate is 2.3 when using the CPI-deflated measure, and slightly lower - 1.9 - when using the PPI-deflated measure. These are quite high estimates, relative to those reported by Hooper et al. (1998), although the standard errors are very large. Overall, income sensitivity estimates are

\footnotetext{
${ }^{11}$ It is possible that the other variables also respond to the disequilibrium. If they do not (that is, statistically insignificant error correction coefficients for the exchange rate and income), then this is equivalent to weak exogeneity of these two variables. Tests for weak exogeneity formally, likelihood ratio tests for the restriction on the $\varphi$ coefficients - indicate that exchange rates appear to be exogenous, while incomes do not. I thank an anonymous referee for suggesting these tests. Also reported in Tables 1 and 2 are asymptotic standard errors; however, as noted by one of the referees, one can only conduct inference using these in certain cases, as noted by Banerjee et al. (1998).
} 
relatively robust. They range from 1.7 to 2 . The price sensitivity is somewhat smaller when identified using the ULC measure. In this case, the price sensitivity is 0.7 . The price coefficients all appear to be statistically significant, while only in the ULC case is the income coefficient statistically significant. ${ }^{12}$

The error correction coefficients in the bottom panel of Table 1 indicate that both export flows and GDP respond to disequilibria in the long-run export relationship, except in the PPI-deflated real rate case. The rate at which exports respond to disequilibrium is about $17 \%$ per quarter in the ULC case.

It is worthwhile spending some time considering which specification is most relevant, since there appears to be evidence of a long-run relationship in all three cases. The most readily interpretable specification involves the ULC deflated real rate, as the results rather unambiguously indicate the presence of only one cointegrating vector, and a substantial response of export flows to both income and exchange rates.

The results are somewhat less promising for imports. As shown in columns 1-3 of Table 2, it turns out that it is not possible to identify a statistically significant effect for the real exchange rate, regardless of the real exchange rate measure used. ${ }^{13}$

After some experimentation, following the lead by Lawrence (1990) and Meade (1991), it turns out that imports excluding computers, computer parts and peripherals can be modelled without reliance on a structural break. Economically speaking, this result makes sense given the boom in trade in computers and parts since 1995, combined with rapid changes in computer prices, has probably altered the underlying demand relationships (Council of Economic Advisers 2001). ${ }^{14}$

Column 4 of Table 2 reports estimates using this alternative measure of imports of goods and services. In this case, a long-run relationship is detected. The income sensitivity is in line with other estimates, and the price sensitivity, while small, is plausible and borderline significant. Chinn (2003) finds that computer and computer part imports are unexplained by

\footnotetext{
${ }^{12}$ The conclusions regarding statistical inference are based on likelihood ratio tests for zero restrictions in the cointegrating vector.

${ }^{13}$ In previous empirical work using a shorter sample period ending at 2001q2, evidence of cointegration is detected only if an exogenous dummy is imposed at 1995q1 (results not reported; see Chinn 2003). Since the economic meaning of such an intervention variable is difficult to discern, this approach is not further pursued in this paper.

${ }^{14}$ Nominal computers and computer parts accounted for a peak of $7 \%$ of total imports in 2000 , declining to about $5 \%$ in 2003 . As early as 1980 , the proportion was less than half of $1 \%$.
} 
Table 2: US Imports Equation, 1975q1-2003q2

\begin{tabular}{|c|c|c|c|c|c|}
\hline Long-run coeff & Pred & $\begin{array}{l}\text { CPI defl. imports } \\
{[1]}\end{array}$ & $\begin{array}{l}\text { PPI defl. imports } \\
{[2]}\end{array}$ & $\begin{array}{l}\text { ULC defl. imports } \\
\text { [3] }\end{array}$ & $\begin{array}{l}\text { PPI defl. imports ex. comp. } \\
{[4]}\end{array}$ \\
\hline C.V.[asy.] & & 1,1 & 1,1 & 1,1 & 1,1 \\
\hline C.V.[f.s.] & & 1,1 & 1,1 & 0,1 & 1,1 \\
\hline$q$ & $(-)$ & $-0.211(0.150)$ & $-0.115(0.230)$ & $-0.137(0.143)$ & $-0.308^{\dagger}(0.162)$ \\
\hline$y$ & $(+)$ & $2.287^{* * *}(0.069)$ & $2.293 * * *(0.085)$ & $2.234^{* * *}(0.092)$ & $2.002^{* * *}(0.057)$ \\
\hline lag & & 2 & 2 & 2 & 4 \\
\hline $\mathrm{N}$ & & 114 & 114 & 114 & 114 \\
\hline \multicolumn{6}{|c|}{ Error correction coefficients } \\
\hline $\operatorname{Im}$ & $(-)$ & $-0.026(0.020)$ & $-0.020(0.017)$ & $0.022(0.019)$ & $-0.075^{* *}(0.026)$ \\
\hline$q$ & $(+)$ & $0.005(0.023)$ & $-0.001(0.015)$ & $-0.007(0.023)$ & $-0.006(0.025)$ \\
\hline$y$ & $(+)$ & $0.031^{* * *}(0.006)$ & $0.027 * * *(0.005)$ & $0.029^{* * *}(0.006)$ & $0.030^{* * *}(0.008)$ \\
\hline
\end{tabular}

Notes: 'Coeff is the coefficient from equation (A1) (standard errors in parentheses). 'Pred' indicates predicted sign. 'C.V.' indicates the number of cointegrating vectors identified using the trace, maximal eigenvalue statistics, and the $1 \%$ significance level; [asy.] indicates asymptotic critical values, while [f.s.] indicates use of finite sample critical values (Cheung and Lai 1993). Coefficients are long-run parameter estimates from the Johansen procedure described in the text. Lag is the number of lags in the VAR specification of the system. $N$ is the effective number of observations included in the regression.

* Denotes significance at the $10 \%$ level.

** Denotes significance at the $5 \%$ level.

*** Denotes significance at the $1 \%$ level, using a likelihood ratio test for the relevant zero restriction.

${ }^{\dagger}$ Significant at the $12 \%$ level. 
movements in the PPI deflated real exchange rate, suggesting that aggregation of non-computer and computer imports is inappropriate.

One implication of the exchange rate coefficient estimates is that the Marshall-Lerner condition only barely holds even in the long run; the sum of the (absolute value of the) point estimates from the preferred specifications is just over unity. Thus, if the trade balance is already in deficit, then a depreciation may in fact result in a deterioration, rather than improvement, of the trade account.

It may be useful to summarize at this point what has been learned in revisiting this subject. Regarding the adjustment process for US trade flows, these results pave the way for a modest revision of the conventional wisdom. Consider the top panel of Table 3, which compares various estimates of import elasticities. While the estimated income sensitivity obtained in this study appears much in line with those obtained by Hooper et al., and most other studies (see Lawrence 1990; Mann 1999, Table 8.2), the price elasticities provide a different story. The estimate of non-computer import price sensitivity in column 4 is correctly signed, in contrast to those obtained

Table 3: Selected Estimates of Trade Elasticities

\begin{tabular}{|c|c|c|c|c|}
\hline \multicolumn{5}{|c|}{ Panel 3.1: Imports } \\
\hline & $\begin{array}{l}\text { Hooper et al. } \\
\text { (1998) }\end{array}$ & $\begin{array}{l}\text { Boyd }^{\mathrm{a}} \text { et al. } \\
(2001)\end{array}$ & $\begin{array}{l}\text { Chinn } \\
\text { total }\end{array}$ & $\begin{array}{l}\text { Chinn ex. } \\
\text { comp. }\end{array}$ \\
\hline Long-run coeff. & [1] & {$[2]$} & [3] & {$[4]$} \\
\hline$q$ & $0.11-0.13$ & -1.42 & -0.115 & -0.308 \\
\hline$y$ & $2.11-2.22$ & 0.45 & 2.293 & 2.002 \\
\hline Sample & $1960-94$ & $1970-95$ & $1975-2003$ & 1975-2003 \\
\hline \multicolumn{5}{|c|}{ Error correction coefficients } \\
\hline $\operatorname{Im}$ & 0.04 to -0.10 & -0.238 & -0.020 & -0.075 \\
\hline
\end{tabular}

Panel 3.2: Exports

\begin{tabular}{llll}
\hline Long-run coeff. & $\begin{array}{l}\text { Hooper et al. (1998) } \\
{[1]}\end{array}$ & $\begin{array}{l}\text { Boyd } \\
{[2]}\end{array}$ & $\begin{array}{l}\text { Chinn total } \\
{[3]}\end{array}$ \\
\hline$q$ & $0.52-0.72$ & 1.42 & 0.726 \\
$y$ & $1.68-1.81$ & 0.65 & 1.615 \\
Sample & $1960-94$ & $1970-95$ & $1975-2003$ \\
Error correction coefficients & & -0.168 \\
Ex & -0.20 to -0.35 & -0.238 & \\
\hline
\end{tabular}

Notes: 'Coeff' is long-run parameter estimates from the Johansen procedure described in the text. Real exchange rate index is unit labour cost deflated, unless otherwise noted. 'Error correction' is the reversion coefficient for the relevant trade flow. Source: Hooper et al. (1998), Boyd et al. (2001) and author's calculations.

${ }^{\mathrm{a}}$ Imports and export exchange rate elasticities constrained to be equal and opposite. 
by Hooper et al. On the export side the estimated export elasticity with respect to the exchange rate is noticeably higher than that reported by Hooper et al.

\section{Policy Implications}

What policy implications follow from these empirical results? It is not the intent of this study to make predictions regarding the future path of the US trade deficit. Indeed, doing so would require making predictions regarding the future paths of income at home and abroad, as well as the value of the dollar. ${ }^{15}$

However, one can draw three general conclusions from the empirical analyses. First, for imports the relevant measure of the dollar - a broadbased PPI-deflated index - indicates that the US currency is still relatively strong, as it is not too far below its 1985 peak. Hence, the elevated level of imports is partly explicable. On the other hand, the ULC-deflated value of the dollar, which exports appear to respond to, is some $50 \%$ below that peak. This latter point suggests that there may be limited scope for increases in export based upon expenditure switching, although in principle there is nothing that prevents a very large dollar decline. Indeed, the argument that intervention by East Asian central banks is preventing additional dollar depreciation ${ }^{16}$ suggests that much more expenditure switching can occur if these activities cease.

Second, the import price sensitivity remains quite low. This finding suggests that improvements in the US trade balance will likely require large movements in the value of the dollar, especially when starting from an initial position of deficit. For instance, if the dollar had been $20 \%$ weaker than it actually was in 2003q2, then the steady-state level of exports would have been $\$ 1.29$ trillion instead of the actual $\$ 1.01$ trillion, while imports would have been less by only a relatively small amount, at $\$ 1.44$ trillion instead of the actual level of $\$ 1.54$ trillion.

Third, it is therefore likely that any improvement in the US trade balance will necessarily incorporate some realignment of growth trends. Although the export income elasticity is now closer to the import income elasticity, it is still somewhat smaller, so a long-term closing of the gap must be accompanied by either a substantially lower US income growth or accelerated foreign income growth (e.g. in the euro area; see Faruqee

\footnotetext{
${ }^{15}$ Forecasting these variables at any time would be an enterprise fraught with hazards, but in this period of uncertainty it would seem to be particularly foolhardy to speculate.

${ }^{16}$ See the discussion in Chapter 5 of BIS (2004) regarding global rebalancing scenarios focused on East Asia.
} 
2004). The former is not predicted by most macroeconomic forecasters, and the latter has been a long hoped for - and long unfulfilled - event.

\section{Conclusions}

There are several revisions to our general understanding of the behaviour of US trade flows that arise from this and other recent studies. First, while a stable long-run relationship exists for US exports, the real exchange rate and rest-of-world income, aggregate US imports are quite difficult to model, regardless of the real exchange rate measure used.

Second, aggregate imports excluding computers, peripherals and parts do appear to be related to the real exchange rate and income in a stable fashion. On the other hand, it is not possible to isolate a plausible demand function for imports of computers. The exchange rate coefficient is invariably wrong-signed, while income picks up a large proportion of the variation, indicating that it is difficult to empirically model aggregate imports. Consequently, analysts may have to resign themselves to being largely unable to explain roughly $5 \%$ of US nominal imports in the standard fashion.

Third, even non-computer imports appear relatively impervious to exchange rate fluctuations; the exchange rate elasticity is only about onehalf that of exports, and is only borderline significant.

Finally, the finding of asymmetry in income elasticities, first pointed out by Houthakker and Magee (1969) persists, albeit in a slightly diminished form. One interesting question for the future is whether the convergence in income elasticities will continue.

Menzie D. Chinn

LaFollette School of Public Affairs; and Department of Economics

University of Wisconsin

1180 Observatory Drive

Madison, WI 53706-1393

USA

mchinn@lafollette.wisc.edu

\section{References}

Arora, Vivek, Steven Dunaway and Hamid Faruqee (2001), 'Chapter II: Sustainability of the U.S. External Current Account Deficit', United States: Selected Issues. IMF Country Report No. 01/149. Washington, DC: IMF, August. 
Incomes, Exchange Rates and the US Trade Deficit, Once Again 465

Baily, Martin (2002), 'Persistent Dollar Swings and the U.S. Economy', Mimeo, IIE, Washington, DC (October).

Bank for International Settlements (2004), Annual Report. Basle: Bank for International Settlements.

Banerjee, Anindya, Juan Dolado, John W. Galbraith and David Hendry (1993), Cointegration, Error Correction, and the Econometric Analysis of Non-Stationary Data. Oxford: Oxford University Press.

Banerjee, Anindya, Juan Dolado and Ricardo Mestre (1998), 'Error Correction Mechanism Tests for Cointegration in a Single-Equation Framework', Journal of Time Series Analysis, 19(3), 267-83.

Bayoumi, Tamim (2003), 'Estimating Trade Equations from Bilateral Data', Mimeo, IMF, Washington, DC (December).

Boyd, Derick, Guglielmo Maria Caporale and Ron Smith (2001), 'Real Exchange Rate Effects on the Balance of Trade: Cointegration and the Marshall-Lerner Condition', International Journal of Finance and Economics, 6, 187-200.

Cheung, Yin-Wong, and Kon S. Lai (1993), 'Finite-Sample Sizes of Johansen's Likelihood Ratio Tests for Cointegration', Oxford Bulletin of Economics and Statistics, 55(3), 313-28.

Chinn, Menzie (1991), 'Beware of Econometricians Bearing Estimates: Policy Analysis in a "Unit Root" World', Journal of Policy Analysis and Management, 10(4 Fall), 546-67.

Chinn, Menzie (2004), 'Measuring Real Effective Exchange Rates' in G. DeBrouwer and Y. Wang (eds), Exchange Rate Regimes in East Asia. London: Routledge Curzon.

Chinn, Menzie (2003), 'Doomed to Deficits? Aggregate U.S. Trade Flows Revisited', NBER Working Paper No. 9521.

Council of Economic Advisers (2001), Economic Report of the President. Washington, DC: U.S. GPO, January.

Devereux, Michael B., and Charles Engel (2002), 'Exchange Rate Pass-Through, Exchange Rate Volatility, and Exchange Rate Disconnect', NBER Working Paper No. 8858.

Dooley, Michael P., David Folkerts-Landau and Peter Garber (2003), 'An Essay on the Revived Bretton Woods System', NBER Working Paper No. 9971.

Faruqee, Hamid (2004), 'Chapter IV: Global Rebalancing of Current Accounts: A Euro Area Perspective', The Euro Area: Selected Issues. IMF Country Report. Washington, DC: IMF.

Gagnon, Joseph E. (2003), 'Productive Capacity, Product Varieties, and the Elasticities Approach to the Trade Balance', International Finance and Discussion Paper No. 2003-781, Board of Governors of the Federal Reserve System, Washington, DC. 
Goldstein, Morris, and Mohsin Khan (1985), 'Income and Price Effects in Foreign Trade', in R. Jones and P. Kenen (eds), Handbook of International Economics, Vol. 2. Amsterdam: Elsevier (Chapter 20).

Golub, Stephen (1994), 'Comparative Advantage, Exchange Rates and the Sectoral Trade Balances of the Major Industrial Countries', IMF Staff Papers, 41, 286-313.

Hargreaves, Derek, and Carlton Strong (2003), 'JP Morgan Effective Exchange Rates: Revised and Modernized', Economic Research Note. New York: J. P. Morgan Chase Bank, May.

Helkie, William, and Peter Hooper (1988), 'The U.S. External Deficit in the 1980's: An Empirical Analysis', in R. Bryant, G. Holtham and P. Hooper (eds), External Deficits and the Dollar: The Pit and the Pendulum. Washington, DC: Brookings Institution Press.

Hooper, Peter, Karen Johnson and Jaime Marquez (1998), 'Trade Elasticities for G-7 Countries', International Finance Discussion Papers No. 609, Federal Reserve Board, Washington, DC (April). Revised version published as Princeton Studies in International Economics No. 87. Princeton, NJ: Princeton University, 2000.

Houthakker, Hendrik, and Stephen Magee (1969), 'Income and Price Elasticities in World Trade', Review of Economics and Statistics, 51, 111-25.

Johansen, Søren (1988), 'Statistical Analysis of Cointegrating Vectors', Journal of Economic Dynamics and Control, 12, 231-54.

Johansen, Søren, and Katerina Juselius (1990), 'Maximum Likelihood Estimation and Inference on Cointegration - With Applications to the Demand for Money', Oxford Bulletin of Economics and Statistics, 52, 169-210.

Johnston, Louis D., and Menzie Chinn (1996), 'How Well Is America Competing? A Comment on Papadakis', Journal of Policy Analysis and Management, 15(1), 68-81.

Krugman, Paul (1989), 'Differences in Income Elasticities and Trends in Real Exchange Rates', European Economic Review, 33, 1031-54.

Lawrence, Robert Z. (1990), 'U.S. Current Account Adjustment: An Appraisal', Brookings Papers on Economic Activity, 2, 343-82.

Leahy, Michael P. (1998), 'New Summary Measures of the Foreign Exchange Value of the Dollar', Federal Reserve Bulletin, October, 811-18.

Mann, Catherine (1999), Is the U.S. Trade Deficit Sustainable? Washington, DC: IIE.

Meade, Ellen (1991), 'Computers and the Trade Deficit: The Case of the Falling Prices', in P. Hooper and D. Richardson (eds), International Economic Transactions: Issues in Measurement and Empirical Research. NBER Studies in Income and Wealth, Vol. 55. Chicago: University of Chicago Press.

Meade, Ellen (1992), 'A Fresh Look at the Responsiveness of Trade Flows to Exchange Rates', Paper prepared for the Annual Meetings of the Western Economic Association, San Francisco, 9-13 July (June 1992). 
Obstfeld, Maurice, and Kenneth Rogoff (2000), 'Perspectives on OECD Economic Integration: Implications for U.S. Current Account Adjustment', Global Economic Integration: Opportunities and Challenges. Kansas City: Federal Reserve Bank of Kansas City.

Rose, Andrew (1991), 'The Role of Exchange Rates in a Popular Model of International Trade: Does the "Marshall-Lerner" Condition Hold?', Journal of International Economics, 30, 301-16.

Rose, Andrew, and Janet Yellen (1989), 'Is there a J-Curve?', Journal of Monetary Economics, 24, 53-68.

Whelan, Karl (2000), 'A Guide to the Use of Chain Aggregated NIPA Data', Finance and Economics Discussion Papers No. 2000-35, Board of Governors of the Federal Reserve System, Washington, DC, June.

Zanello, Allesandro, and Dominique Desruelle (1997), 'A Primer on the IMF's Information Notices System', Working Paper No. WP97/71, International Monetary Fund, Washington, DC.

\section{Appendix A: Data Sources and Description}

\section{Exchange Rate Indices}

- US 'Major' trade-weighted exchange rate (CPI-deflated). Source: Federal Reserve Board website, http://www.federalreserve.gov/releases/ h10/Summary/indexnc_m.txt. Weights are listed at http://www.federalreserve.gov/releases/h10/Weights/. Data accessed 15 December 2003. See Leahy (1998) for details.

- 'Broad' trade-weighted real exchange rates (PPI-deflated). $1990=100$, 1990 trade weights for 1987-2001; 1980 trade weights for 1970-86 (weights exclude China). Hong Kong series adjusted by Hong Kong retail price index. Source: J. P. Morgan, http://www2.jpmorgan.com/ MarketDataInd/Forex/REXB.bin. Data accessed December 2003. For a description of the series construction, see Hargreaves and Strong (2003).

- Trade-weighted real exchange rates (ULC-deflated). $1995=100,1988-$ 90 trade weights. Source: for 1978q1-2003q3, International Financial Statistics, accessed 14 December 2003, line reu. ULCs are filtered using the HP filter. For data up to $1977 \mathrm{q} 4$, series spliced to previous reu series $(1985=100)$, accessed in 1994. See Zanello and Desruelle (1997) for details regarding the reu series. 


\section{Trade Flows, Economic Activity}

- Real imports and exports of goods and services (1996 chain-weighted dollars). Source: Federal Reserve Bank of St Louis (FRED) website.

- Real imports and exports of non-computer goods and services, and of non-computer goods (1996 chain-weighted dollars). Source: personal communication from BEA, and post-1987, calculated using Tornqvist approximation. See Whelan (2000) for an explanation of the procedure. Computer imports before 1987 are measured using fixed-weight measures (the difference between chain- and fixed-weighted imports was minor in 1987q1), extending back to 1970. For observations recorded as NA, it was assumed computer imports were $\$ 0.05$ billion.

- US GDP (1996 chain-weighted dollars). Source: FRED II website.

- Rest-of-world GDP (1996 dollars). US exports weighted rest-of-world GDP. Source: personal communication from Federal Reserve. Updated over 2003q1-2003q2 period using regression on current and four lags of industrial country industrial production (in first differences).

\section{Appendix B: Estimation Methodology}

The estimation is implemented using a maximum likelihood procedure, which simultaneously identifies the existence or absence of long-run relationships between the levels of the variables, estimates those long-run relationships if they exist, and also detects the short-run dynamics.

The estimation procedure is predicated upon the variables of interest being integrated of order one, or I(1). ADF tests (with and without trends) fail in all cases to reject the unit root null (where the lag lengths are selected using the AIC). Furthermore, tests on the first difference of all the variables indicate stationarity.

Estimation proceeds in two steps: (1) Lag length selection and (2) estimation of the vector error correction model (VECM). The latter step entails interpretation of the cointegration results, and examination of the short-run dynamics.

The lag length is determined by the minimum AIC for the unconstrained VAR, with the lag lengths of up to eight lags considered. In all cases, the twolag specification yields the minimum AIC. No deterministic trends allowed in the variables or cointegrating vectors, except for the ULCs-exports equation. In this case deterministic trends are allowed in the variables, given the superior fit, according to the AIC. 
The Johansen (1988) and Johansen and Juselius (1990) maximum likelihood procedure is implemented in order to test for cointegration and identify the cointegrating vector. For the import system, the procedure estimates the following VECM:

$$
\begin{aligned}
\Delta i m_{t}^{U S}= & \gamma_{10}+\varphi_{1}\left(i m_{t-1}^{U S}-\beta_{1} q_{t-1}-\beta_{2} y_{t-1}^{U S}\right)+\gamma_{11} \Delta i m_{t-1}^{U S}+\gamma_{12} \Delta q_{t-1} \\
& +\gamma_{12} \Delta y_{t-1}^{U S}+\varepsilon_{1 t} \\
\Delta q_{t}= & \gamma_{20}+\varphi_{2}\left(i m_{t-1}^{U S}-\beta_{1} q_{t-1}-\beta_{2} y_{t-1}^{U S}\right)+\gamma_{21} \Delta i m_{t-1}^{U S}+\gamma_{22} \Delta q_{t-1} \\
& +\gamma_{23} \Delta y_{t-1}^{U S}+\varepsilon_{2 t} \\
\Delta y_{t}^{U S}= & \gamma_{30}+\varphi_{3}\left(i m_{t-1}^{U S}-\beta_{1} q_{t-1}-\beta_{2} y_{t-1}^{U S}\right)+\gamma_{31} \Delta i m_{t-1}^{U S}+\gamma_{32} \Delta q_{t-1} \\
& +\gamma_{33} \Delta y_{t-1}^{U S}+\varepsilon_{3 t} .
\end{aligned}
$$

For exports, the system estimated is:

$$
\begin{aligned}
\Delta e x_{t}^{U S}= & \gamma_{40}+\varphi_{4}\left(e x_{t-1}^{U S}-\delta_{1} q_{t-1}-\delta_{2} y_{t-1}^{R o W}\right)+\gamma_{41} \Delta e x_{t-1}^{U S}+\gamma_{42} \Delta q_{t-1} \\
& +\gamma_{43} \Delta y_{t-1}^{R o W}+\varepsilon_{4 t} \\
\Delta q_{t}= & \gamma_{50}+\varphi_{5}\left(e x_{t-1}^{U S}-\delta_{1} q_{t-1}-\delta_{2} y_{t-1}^{R o W}\right)+\gamma_{51} \Delta e x_{t-1}^{U S}+\gamma_{52} \Delta q_{t-1} \\
+ & \gamma_{53} \Delta y_{t-1}^{R o W}+\varepsilon_{5 t} \\
\Delta y_{t}^{R o W}= & \gamma_{60}+\varphi_{6}\left(e x_{t-1}^{U S}-\delta_{1} q_{t-1}-\delta_{2} y_{t-1}^{R o W}\right)+\gamma_{61} \Delta e x_{t-1}^{U S}+\gamma_{62} \Delta q_{t-1} \\
& +\gamma_{63} \Delta y_{t-1}^{R o W}+\varepsilon_{6 t} .
\end{aligned}
$$

Two test statistics for testing the alternative of cointegration against the null of no cointegration are calculated: the trace and the maximum eigenvalue statistic. Both are referred to, although generally they will agree on the existence of a cointegrating relationship, and the number of cointegrating vectors. ${ }^{17}$ In all the specifications reported, using the $1 \%$ asymptotic critical values, both the trace and maximal eigenvalue statistics indicate the presence of one cointegrating vector.

There are also additional specification issues related to the allowance for constants and trend terms in either the data or the cointegrating vector. For most of the specifications, the AIC selects a model with deterministic trends allowed in the data, but not in the cointegrating vector. ${ }^{18}$

\footnotetext{
${ }^{17}$ Cheung and Lai (1993) have shown that it is often important to account for degrees of freedom when using highly parametrized VARs. However, with the short lag lengths implemented and relative parsimony of the specifications, the conclusions would be unchanged using finite sample critical values.
}

${ }^{18}$ See Chapter 8 of Banerjee et al. (1993) for additional discussion. 